\title{
Study on the Online Office System for Tourism Management
}

\author{
Xiang Hua-ping, Chen Chao \\ Jiangxi College Of Foreign Studies
}

\begin{abstract}
Tourism is a sunrise industry with huge economic potential and broad market prospect. While developing tourism, the rapid development of network technology has changed people's inquiry and reservation of tourism and transportation, Information technology is the most advanced productivity element in today's society. The rapid development and wide application of information technology has made e-commerce real with online office system for all fields. In the paper, combined with the disadvantages of traditional management modes, the author explores the establishment, inquiry and management of tourism management system. Under the circumstance of Linux network operation system, with the employmentof MySQL technology of network database, it aims to develop a set of online office system for tourism management in Web script PHP programming environment with MySQL database technology.
\end{abstract}

Key words- tourism management; online office; network operation system; network database

\section{INTRODUCTION}

Tourism is a sunrise industry with huge economic potentials and broad market prospect. Its economic output value and employment opportunities account for ten percent in the world GDP and employment respectively as the largest field. The economic effect brought by tourism is going to constantly promote with greater development of world economy. Chinese tourism even has a greater prospect with infinite business opportunities. Tourism has generated new consumption market with the formation of new economic field, that is, tourism economy, while bringing huge people flow, materials, fortunes, technologies, transportation and information.

With the rapid development of information age, our business mode of tourism has been changed greatly with new technology and the superiority of network inquiry. Nowadays, with the new technology, "free-ticket air travel" has been available. Tourism agencies should timely update the tourism routes and pack products to obtain larger market shares with the advantages of network inquiry. In this paper, the author hopes to provide a platform for public's inquiry and communication with better application by exploring the establishment, inquiry and management of local tourism service resources.

\section{THE NECESSITY FOR THE INFORMATIZATION OF TOURISM MANAGEMENT}

\section{A. The informatization of tourism management is the objective requirement of information age}

Tourism is an industry involving many fields with strong correlation. Only if the components inside the tourism as well as the relationship between tourism and other industries are coordinated with each other, tourism economy can operate smoothly. Therefore, the operation of tourism is constantly mobile with wide much emphasis on overall cooperation and resource sharing. The management efficiency of tourism as well as the growth of interest also requires organic cooperation with prominent resource sharing. At present, both the flow frequency and width of modern tourism have been improved compared to traditional tourism. In order to realize an overall industrial cooperation, modern regulation and communication are needed. That is to say, appropriate management of tourism information flow should be seen as the core in information age.

\section{B. The reliance of tourism on information is the internal motivation for the informatization of tourism management}

The tourism industry is vulnerable to various factors, which can be easily affected by macro or micro natural factors, political and economical factors, so it is especially important for scientific decision making by effectively acquiring information. The dependence of tourism on information indicates that information and information technology are important for tourism. Management informatization is determined by the essential nature of tourism.

\section{TECHNICAL SCHEME OF ONLINE OFFICE MANAGEMENT SYSTEM AND ITS REALIZATION}

The initial prototype of e-government is office automation. The so-called office automation, which is short for OA, refers to transfer partial human's business to equipment by technical means so that the office business can be finished together by equipment of officers. Compared to the later information system, short for IS and decision support system, short for DSS, OA gives more emphasis on the application of technologies and automatic office equipment but with less employment of management models.

Since the 1970s, development of office automation in our country has experienced three stages. The main mark of the first stage is the wide application of office equipment such as fax machine, typewriter and copier and so on; The main mark of the second stage is the wide application of computers and printers for character processing, table processing, word layout and output as well as management of personnel financial information and so on. The major mark of the third stage is the universal application of network technologies, which has 
realized the sharing of document, network printing and management of online database. The Fig .1 has showed the three development stages of office automation in our country.

E-government is originated from the office automation. By far, OA is still an important part of e-government system. It is the precondition and basis for establishing e-government system to further promote office automation. The mature and perfect e-government system can only be established with the solid office automation.

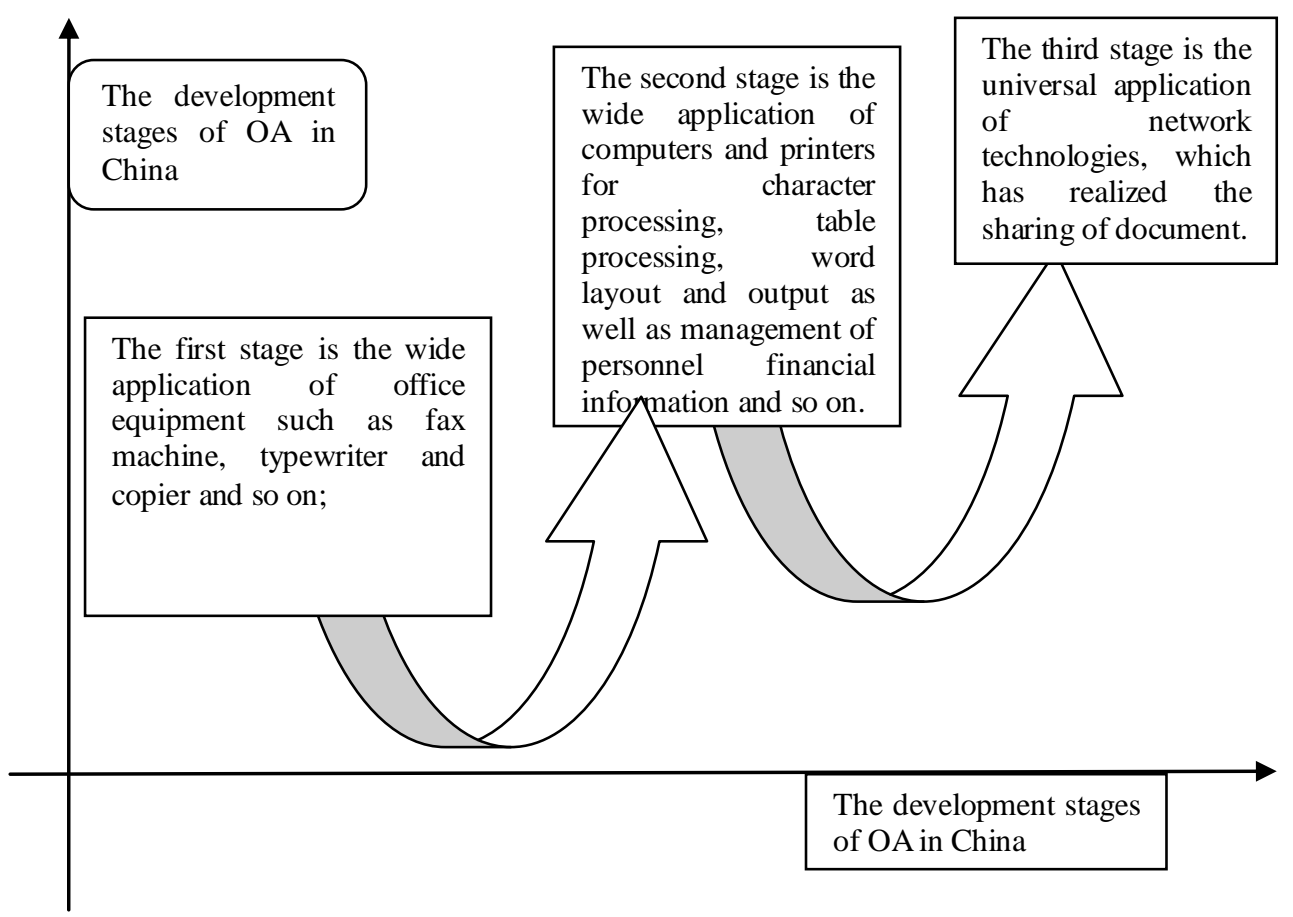

Figure 1. Three development stages for office automation in China

\section{THE MODULE FRAMEWORK OF THE DATABASE FOR TOURISM MANAGEMENT}

The biggest advantage of computer is able to process large amount of data rapidly and accurately. Therefore, data processing has been its basic function and key technology since its emergence. The main function of data processing is to classify, organize, code, store, search and maintain the data, and the database technology is right the product of data processing technology with mature development. In today's information society with e-government management, administrative management can't live without the support of database technology based on computers and computer network technology. The database technology is the base of tourism industry for online management, which plays an important role in establishing online management information system for tourism. In order to implement information management, the top job is to establish a database for the management objects and contents in tourism industry. Management objects in tourism industry includes travel agencies, hotels, tourist transportation and tourist spots. The travel agency is the agent for travelers to realize traveling since it helps to arrange routes, launch products, attract visitors and arrange activities during the trip for travelers. Hotels include hotels and restaurants, which can offer food and rooms for travelers during their trips. Tourist communications include planes, trains, ships and automobiles with their schedules, standards and prices so as to provide convenient transportation. Tourist sports are responsible for introducing the local cities, tourist spots, routes as well as prices. According to the management objects of tourism, the database can be divided into four modules, which are travel agencies, hotels, tourist communications and tourist spots. The Fig .2.shows us the database framework of Tourist Administration. 


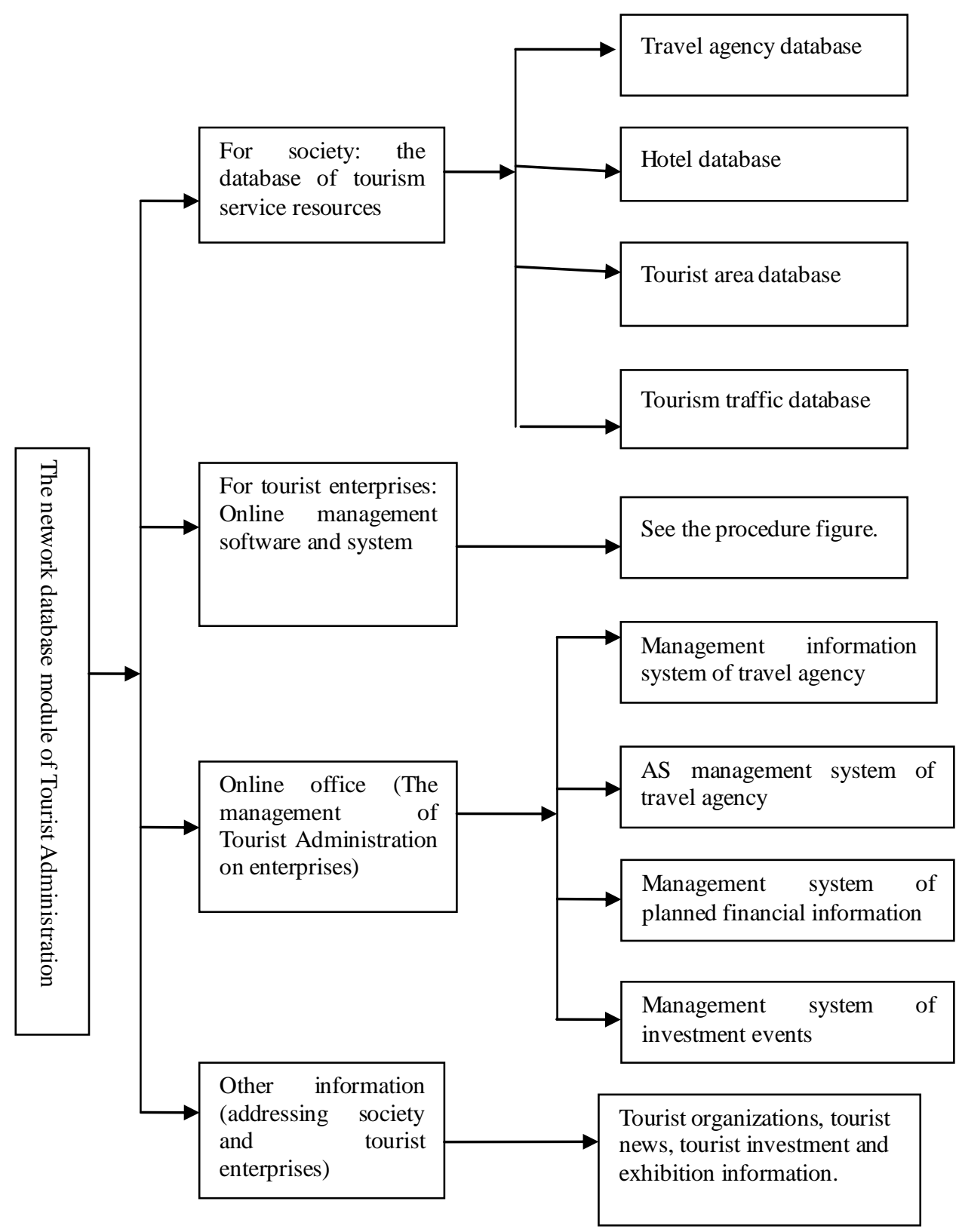

Figure 2. Database module of Tourist Administration

\section{CONCLUSION}

The online management objects of tourism are four operation units for tourists, which are tourism agencies, hotels, tourism transportation (planes, trains, ships and automobiles) and tourist spots. In order to implement online management, three conditions should be satisfied. The first step is to build local area network. The Tourist Administration has built intranet and extranet. The second step is to establish a data framework for the management module with the development and management of information system. The third step is that all tourist enterprises should be connected to network by establishing their own websites, which is convenient for receiving management from Tourist Administration and offering information to public. In this paper, there are mainly two objects for the application of online industry management, which are administrator, the Tourist Administration and the tourist enterprises. The purpose of this paper is to apply networking information management to tourism management so as to design and develop convenient, fast, effective and safe modern management methods.

\section{REFERENCES}

[1] Buhalis D, Law R. Progress in information technology and tourism management: 20 years on and 10 years after the Internet-The state of eTourism research[J]. Tourism Management, 2008, 29(4):609-623.

[2] Litvin S W, Goldsmith R E, Pan B. Electronic word-of-mouth in hospitality and tourism management[J]. Tourism Management, 2008, 29(3):458-468. 
[3] Sharpley R. Rural tourism and the challenge of tourism diversification - The case of Cyprus. Tourism Management, 23(3), 233-244[J]. Tourism Management, 2002, 23:233-244.

[4] Stamboulis Y, Skayannis P. Innovation strategies and technology for experience-based tourism. Tourism Management, 24(1), 35-43[J]. Tourism Management, 2003, 24:35-43.

[5] Law R, Qi S, Buhalis D. Progress in tourism management: A review of website evaluation in tourism research[J]. Tourism Management, 2010, 31(3):297-313.

[6] Kajanus M, Kangas J, Kurttila M. The use of value focused thinking and the A'WOT hybrid method in tourism management.[J]. Tourism Management, 2004, 25(03):499-506.

[7] Garrod B, Fyall A. Beyond the rhetoric of sustainable tourism? Tourism Management, 19(3), 199-212[J]. Tourism Management, 1998, 19.
[8] Page S J, Page S J. Tourism management: managing for change.[J]. Tourism Management Managing for Change, 2003.

[9] Guttentag D A. Virtual reality: applications and implications for tourism. Tourism Management[J]. Tourism Management, 2010, 31:637-651.

[10] Jansen-Verbeke M. Leisure shopping: A magic concept for the tourism industry? Tourism Management, 12(1), 9-14[J]. Tourism Management, 1991, 12:9-14.

[11] Hall C M, Page S J. Progress in Tourism Management: From the geography of tourism to geographies of tourism - A review $[\mathrm{J}]$. Tourism Management, 2009, 30(1):3-16.

[12] Tao T C H, Wall G. Tourism as a sustainable livelihood strategy. Tourism Management, 30, 90-98[J]. Tourism Management, 2009, 30:90-98. 